\title{
Uma princesa solitária
}

\section{Jacqueline Hermann}

AZEVEDO, Francisca Nogueira de. Carlota Joaquina na corte do Brasil. Rio de Janeiro: Civilização Brasileira, 2003.

“[...] se fico aqui por muito tempo, morro, porque minha enfermidade física nem a moral não posso curar aqui [...]", escreveu Carlota Joaquina a seu ex-secretário José Presas, em 1813, cansada, doente e abatida pelos reveses sofridos desde que chegara ao Brasil acompanhando o príncipe D. João. Depois de cinco anos nos trópicos, sofria ataques de asma, problemas gástricos e "explosões de erisipela ao rosto e cabeça". Esta imagem já fragilizada da princesa em nada lembra aquela mulher raivosa e de pouca compostura com a qual identificamos essa personagem histórica, isso para só falar dos modos e não da única atividade que parecia ter neste lado do Atlântico: caçar homens sem pejo e deleitar-se com eles à exaustão.

O livro de Francisca Nogueira de Azevedo que ora nos chega vem destruir definitivamente essa construção estereotipada e caricatural que alguns cronistas e romancistas criaram para Carlota Joaquina. Retrato deformado e atento ao que pôde haver de mais irrelevante política e historicamente, essas interpretações aprisionaram a princesa espanhola à alcova, não só minimizando como procurando mesmo ignorar a importância política e diplomática de Carlota nos gravíssimos acontecimentos vivenciados pela Europa, pelos reinos ibéricos e pela América no início do século XIX. Mas não se pense que a autora, visando desconstruir o estereótipo, cai na armadilha de revelar uma princesa frágil e manipulada pelos acontecimentos. Ao contrário, o que seu livro descortina é uma mulher de excepcional visão política, atuante e ciosa de suas prerrogativas monárquicas, mas que tem seus movimentos e projetos limitados pelo enredo do tempo em que viveu e pela especificidade do gênero feminino a que pertencia.

Trata-se, portanto, de trabalho de refinada história política e diplomática no que esta pode ter mais 
clássica e reveladora de um tempo, conjugado à história de uma personagem de sangue real, embora nada ilustre pelo que até então se conhecia. É trabalho que se filia, assim, à chamada nova história política e que inova também pela escolha e análise das fontes: a correspondência ativa, passiva e correlata referente a Carlota Joaquina, reunindo um conjunto epistolar disperso em arquivos espanhóis, portugueses, argentinos e ingleses, além de relatórios, manifestos e propaganda política, perfazendo mais de 1.400 documentos.

A organização desse vasto material e a reconstrução dos diálogos estabelecidos entre os inúmeros destinatários e a princesa, os temores e conspirações que os projetos de Carlota provocaram, bem como os esforços empreendidos para isolá-la e neutralizar seus movimentos, demonstram acuidade e controle seguro da imensa documentação arrolada e analisada, estruturada a partir da montagem de um verdadeiro quebra-cabeça, no qual se encontram a política, a diplomacia e parte da vida pessoal da personagem. Parte porque, e esse é outro mérito do livro em tempos de tanta exposição e invasão de privacidade, o livro concentra-se na atuação políti- ca de Carlota, não se atendo em nenhum momento a qualquer aspecto relacionado a sua vida amorosa ou sexual.

O livro está dividido em cinco capítulos e inicia-se ainda em Lisboa às vésperas da transmigração da família real. Filha de Carlos IV e Maria Luísa, neta de Luís XV, Carlota conheceu o luxo e o fausto da corte espanhola no auge da ilustração e da imitação de Versalhes. Depois do casamento com o infante D. João de Bragança, com apenas 10 anos, foi morar em Lisboa na época da Viradeira de D. Maria I, tempo de recuo do iluminismo e de retomada da rígida moral religiosa e conservadora no paço português. Seu estranhamento foi imenso e a adapatação dolorosa, sentimentos que só foram se agravando com o espectro da invasão napoleônica na península. Às vésperas do inevitável embarque para o Brasil, apela, implora aos reis espanhóis que intercedam por ela e seus filhos, mas os compromissos políticos e diplomáticos com a França, e a aliança de Portugal com os ingleses se sobrepóem aos laços familiares, opção perfeitamente adequada aos princípios monárquicos que regiam o Antigo Regime. Carlota desde cedo demonstrara ao pai sua desconfiança em relação a qual- 
quer aliança com Napoleão, perguntando, ainda em 1798, quando contava apenas 23 anos: "quem assegura a V.M. que o dito Governo [francês], estando oferecendo felicidades com uma mão, com a outra não está armado, e em alguns anos seja forçoso cair?". A princesa atuou como intermediária entre D. João, a essa altura já príncipe regente, e o rei espanhol, acreditando que ao marido não interessava a inimizade entre as duas monarquias ibéricas, muito embora soubesse da força inglesa na política portuguesa. Vê-se, assim, que desde cedo Carlota demonstrou interesse e talento para a política e esteve atenta às questôes de Estado que envolveram Portugal e Espanha, gosto que herdara de sua mãe, acusada por muitos de ter afrancesado em demasia a corte espanhola e de intrometer-se em assuntos políticos.

Mas o empenho de Carlota para aproximar Portugal e Espanha não impediu o envolvimento da princesa em conspiração para afas$\operatorname{tar} \mathrm{D}$. João do governo, visando assumir a regência de Portugal em 1806. D. João não estava preparado para a tarefa assumida prematuramente com o impedimento da mãe, D. Maria I, em 1792, e passava tempos retirado em Vila Viçosa, tradicional reduto dos Bragança, e
Mafra. Deprimido e desinteressado da política, os partidários da princesa procuraram convencê-la de que o marido sofria da mesmo doença mental da mãe, o que o tornava inapto para o governo do reino. Intrigas palacianas da camareira de Carlota frustraram o plano do "carlotismo", e a princesa começou a experimentar o exílio doméstico, situação que conheceria em diversas outras ocasiōes.

A questão de fundo presente no casamento de um príncipe português com uma princesa espanhola na virada do século XVIII para o XIX e em pleno período de expansão napoleônica envolvia pelo menos duas graves e delicadas dimensões: uma referente à geopolítica da época, na qual os dois reinos eram verdadeiros satélites das duas grandes potências rivais, Inglaterra e França, respectivamente; e outra atinente à histórica e dolorosa possibilidade de reedição da União Ibérica, fosse esta sob a liderança portuguesa, agora com sabor de revanche da jamais superada humilhação da submissão aos espanhóis entre 1580 e 1640; fosse ainda com a direção, uma vez mais, de Espanha, inadmissível para Portugal e agora também para Inglaterra, que mantinha seu poder na península, e em parte de 
seus domínios coloniais, através do reino luso. O casamento de um Bragança e uma representante Bourbon era, a essa altura, um esforço de acordo e união diplomática de difícil, para não dizer impossível, possibilidade de sucesso.

Este intróito do livro dá o tom das desconfianças e imensas dificuldades enfrentadas por Carlota Joaquina no Brasil. Os capítulos 2, 3 e 4 dedicam-se a uma análise minuciosa de dois importantes momentos políticos nos quais a princesa teve papel de protagonista. No capítulo 2 entramos em contato com a intenção de Carlota, já no Brasil, de interferir na política espanhola depois da invasão francesa e da prisão de sua família, no início de 1808. Apesar da abdicação de Carlos IV em favor de seu filho, Fernando VII, Napoleão indicou seu irmão, José Bonaparte, para o governo de Espanha. Carlota não se conforma e procura assumir a defesa do comando da Casa de Bourbon, dando início a negociações intensas na corte, como o objetivo de se fazer nomear Regente de Espanha. Essa possibilidade foi viabilizada pelo fim da Lei Sálica, determinada por seu pai em 1789, em sessão secreta, tornando possível a uma mulher dirigir o governo de Espanha. Era projeto ambicioso: obter apoio e confirmação de seu nome, sempre marcado, entre os espanhóis, pela suspeição de que estivesse tramando em nome $\mathrm{D}$. João no intuito de uma nova união das duas coroas; no caso de uma vitória, dificílima, seria preciso ainda depor o preposto de Napoleão ou confiar na derrota dos franceses, o que parecia improvável em 1809.

Este plano e a busca de aderentes à causa de Carlota teve inúmeras idas e vindas e foi marcado pelas características estruturantes da vida política e de corte do Antigo Regime: intrigas, dissimulações, traições, desilusão com os aliados, aumento do número de inimigos, cerceamento de movimentos pelos defensores do que se tornou o "partido" de D. João, com a infiltração de espias em torno da princesa. Esta situação complicar-se-ia ainda mais com o pessoal e decisivo envolvimento de Carlota com a conhecida questão do Vice-reino do Prata, assunto do capítulo 3.

Região disputada entre portugueses e espanhóis desde o século XVII, foi alvo de novo projeto de investida luso-inglesa em 1807, plano desencorajado pelas expectativa, não concretizada, de acordo de Inglaterra com Espanha. Já no Brasil, Carlota deu início às negociações e 
contatos para fazer-se nomear regente do vice-reino do Prata, contando inicialmente com o apoio do inglês Sir Sidney Smith, e do então secretário José Presas. Do lado de D. João, D.Rodrigo era o homem forte e principal desafeto de qualquer pretensão de poder de Carlota Joaquina.

Uma vez mais a ambigüidade da posição da princesa a prejudica dos dois lados: para os espanhóis apoiá-la poderia significar entregar domínios hispânicos nas mãos dos portugueses e ingleses; para os portugueses seus planos estariam sempre comprometidos com a causa espanhola. No caso do Vice-reino do Prata, a autora lança hipótese que contraria a tese de que a ambição de Carlota era ser Rainha de uma Região Platina independente: para Francisca Nogueira de Azevedo o compromisso da princesa sempre fora com a manutenção destes territórios sob domínio dos Bourbon, não só por convicção de ser esta a causa correta a defender, como ainda porque aguardava, talvez ingenuamente, sua nomeação para honra muito maior: a regência do reino espanhol.

No capítulo 4, Diamantes para Montevidéu, a autora demonstra o quanto a política e a causa dos Bour- bon sempre contaram mais do que vaidade ou riqueza pessoal para Carlota: isolada, sem ter com quem contar ou como levantar recursos para a defesa do poder espanhol sobre a região do Prata, empenhou suas melhores jóias para financiar a causa que defendia, provocando assombro entre portugueses e espanhóis. O desprendimento e a disposição da princesa a transformam em, para alguns de seus patrícios, “[...] a Isabela de nuestro tiempo [...]”.

O último capítulo do livro começa como termina o primeiro, com Carlota em prisão domiciliar, mas agora só e doente. Nem mesmo a alegria de voltar a Espanha para o casamento de suas duas filhas com dois de seus irmãos, um deles Fernando VII, feito rei de Espanha em 1814, já na fase de agonia da aventura napoleônica — não fazendo mais sentido sua nomeação como regente - ela pôde experimentar. A morte de D. Maria I em 1816 a impediu de viajar. Quanto à questão do Prata, viu-se uma vez mais traída por todos em quem confiara, tendo que assistir ao processo de libertação das colônias hispânicas da América, insuflado pelos ingleses.

Triste e isolada no "cativeiro de Botafogo", viveu no Brasil como se estivesse em presídio, como escreveu 
certa vez. Impulsiva, inteligente, com gosto e visão política, tinha "alma masculina", como disse Oliveira Lima, pecado gravíssimo para a época. Fica a pergunta se a solidão em relação a D. João, pouco presente na correspondência analisada, foi fruto do deliberado foco na princesa ou se o príncipe, depois rei, foi mesmo tão omisso e manipulado como, mais uma vez, parece. Quanto a Carlota, não resta dúvida de que foi sempre ciosa e orgulhosa de sua posição hierárquica, uma representante à altura dos melhores tempos do Antigo Regime, uma princesa ilustrada que não via contradição entre ilustração e absolutismo monárquico. Fiel à monarquia espanhola e a seus deveres de futura soberana, esteve envolvida direta e pessoalmente em questôes de Estado seríssimas tanto para os reinos ibéricos como para as delicadas relaçôes políticas e diplomáticas entre França e Inglaterra. Em período de abalos profundos nas estruturas monárquicas e de divisóes políticas feitas, muitas vezes, ao sabor dos acontecimentos, as convicções de Carlota Joaquina mantiveram-se inalteradas na defesa das bases do Antigo Regime. As posições inde- pendentes e impetuosas para uma mulher de seu tempo jamais fizeram eco aos primeiros reclamos a favor $\mathrm{da}$ liberdade das mulheres surgidos desde fins do século XVIII. Agiu sempre como uma mulher que aprendera o gosto e o sentido da política, mas não cogitou nunca a hipótese de abrir mão de suas prerrogativas dinásticas, pagando caro tanto pela impertinente audácia feminina como pela ambição e grandiosidade dos projetos que comandou.

Carlota Joaquina na corte do Brasil é, portanto, livro importante não só pela desconstrução definitiva da caricatura e do estereótipo de que foi vítima a princesa, revelando o importante papel político desempenhado por uma perdedora, mas também porque cruza como poucos história do mundo ibérico e européia com história da América, história política e diplomática com intrigas palacianas e história de gênero. História política clássica e novas abordagens historiográficas se encontram para tirar da sombra do quarto a princesa que parecia preferir o burburinho dos gabinetes e o brilho dos grandes salōes palacianos aos fáceis deleites da alcova. 